\title{
Infrastructure: Real Assets and Real Returns
}

\author{
Ron Bird*, Harry Liem and Susan Thorp \\ University of Technology, Sydney \\ Sydney, Australia
The Paul Woolley Centre for Capital Market Dysfunctionality, UTS
Working Paper Series 11 \\ Previous version: September 2011 \\ This version: April 2012
}

\begin{abstract}
Little empirical work has been done on infrastructure as an asset class despite increased allocations by institutional investors. We build a robust factor model of infrastructure returns using US and Australian infrastructure and utility data to test manager claims that infrastructure investments offer benefits via a combination of monopolistic and defensive assets. We find evidence of excess returns and inflation hedging, but not of defensive characteristics. We compare option-based models designed to replicate infrastructure asset returns, and identify the regulatory risk premium. A combination of inflation linked bonds and covered call strategies results in improved defensive and inflation hedging characteristics.
\end{abstract}

Keywords: inflation hedging, regulatory risk premium, infrastructure assets

JEL classification: G12, G14

* Corresponding author.

E-mail: Ron.Bird@uts.edu.au

Phone: +61295147716

Fax: +61 295147711

Room: CM05D.03.22B

PO Box 123, Broadway NSW 2007, Australia

\footnotetext{
The authors wish to acknowledge the generous support of the Paul Woolley Centre at the University of Technology, Sydney (UTS). In addition, Thorp acknowledges support under Australian Research Council (ARC) DP 0877219. The Chair of Finance and Superannuation at UTS receives support from the Sydney Financial Forum (Colonial First State Global Asset Management), the NSW Government, the Association of Superannuation Funds of Australia (ASFA), the Industry Superannuation Network (ISN), and the Paul Woolley Centre, UTS. The authors also wish to thank John Doukas, two anonymous referees, and attendees at the 2011 Paul Woolley Conference in Sydney for their valuable comments and suggestions.
} 


\section{Introduction}

Pension funds around the world have been investing in infrastructure with the aim of providing better long duration, real (inflation adjusted) retirement benefits to members. While infrastructure has been seen as a suitable institutional investment in Australia, Canada and the UK since the 1990s, it has only recently increased in popularity in the US and, unlike hedge funds or private equity, has not been the focus of much academic research, partly because of limited data (Dechant et al., 2010; Martin, 2010; Newell and Peng, 2008).

In this paper we define infrastructure as encompassing the utility sector (power generation and distribution) as well as the 'pure' infrastructure sector (toll roads, communications and airports). Institutional investors most commonly delegate infrastructure investment to managers but may also undertake direct investment (Inderst, 2009). ${ }^{1}$ We consider investment in both listed and unlisted Australian infrastructure assets, either directly or through managed funds. Outside of Australia, where less data is available, we focus on the listed infrastructure markets.

Initially researchers viewed infrastructure as having characteristics akin to real estate: a long life cycle, heterogeneity, illiquidity and inflation hedging ability (Dechant et al., 2010; Newell and Peng 2007, 2008). However, a defining feature of the sector is the prevalence of 'natural monopolies' in the provision of essential services (such as energy or water) and of economies of scale created by large distribution networks (Dimasi, 2010). Researchers now concur that infrastructure is a distinct asset class having oligopolistic or monopolistic characteristics, because of restrictions on ownership and on the uses to which infrastructure can be put. Natural monopolies and industries enjoying economies of scale are often regulated by

\footnotetext{
${ }^{1}$ Infrastructure investment methods are described in detail in the appendix.
} 
government restrictions on prices, returns, output levels or barriers to entry. Consequently, infrastructure investments require compensation for regulatory risk. In many countries, infrastructure consists of mature utilities, increasingly facing deregulation and privatisation (Inderst, 2009). As a result, the ability to deliver superior performance may diminish as the industry matures (deregulates).

We make the following three contributions to literature. First, we suggest style factors common to both US and Australian infrastructure investments. We extend our analysis by applying an asymmetric GARCH model to take account of observed volatility clustering in excess returns and we test both the defensive and the inflation hedging ability of the asset class. We find evidence of excess returns and inflation hedging features in infrastructure investments in the US and Australia. While we do find some desirable characteristics, we caution against sample size and time period biases given the limitations of our data set.

Second, we test the defensive ability of infrastructure investments during equity down markets. We find no evidence of defensive characteristics. Despite claims that it is a defensive sector, Australian listed infrastructure funds performed very poorly during the Global Financial Crisis. ${ }^{2}$

Third, we investigate the possibility of using derivatives to replicate infrastructure returns and the ability of infrastructure investment to realise a return in excess of the regulatory risk premium. We find that in Australia, but not in the US, investors achieved returns in excess of comparable option strategies. Infrastructure investing exposes investors to assets with an unknown amount of political risk so we suggest

\footnotetext{
${ }^{2}$ Notably, large infrastructure firms such as Macquarie and Babcock \& Brown were criticised for 'asset gathering' using leverage, thereby generating transaction, advisory, base and performance fees for the parent company. In March 2009 Babcock and Brown was placed into voluntary administration due to its over-reliance on short-term debt while Macquarie restructured and survived as Intoll Group.
} 
how investors can create the desired defensive and real return payoff profile using a combination of inflation linked bond and covered call option strategies.

We review background literature in Section 2, set out the model in Section 3 and discuss data in Section 4. Section 5 presents our empirical results on the excess returns, downside protection and inflation hedging characteristics of infrastructure. Section 6 focuses on the pricing of regulatory risk, while Section 7 suggests how a synthetic real defensive asset can be constructed that combines the defensive and inflation hedging characteristics of infrastructure. Section 8 provides concluding remarks and suggestions for further research.

\section{Background Literature}

The available empirical work on private infrastructure investment has been surveyed by Dechant et al. (2010), Inderst (2009), Martin (2010), and Newell and Peng (2007, 2008). Newell and Peng (2007) find that during the period from 1995 to 2006, infrastructure investment in Australia exhibited higher returns, but also higher volatility, than equity markets. We suggest this finding is largely attributable to the relatively high leverage employed by the listed infrastructure managers in Australia. The period examined by Newell and Peng (2007) excludes the Global Financial Crisis, during which a number of highly levered infrastructure groups such as Macquarie Infrastructure and Babcock and Brown were forced to liquidate or restructure. Newell and Peng (2008) find that in the US, infrastructure (excluding utilities) underperformed stocks and bonds during the period from 2000 to 2006, while utilities outperformed stocks and bonds. Bitsch et al. (2010) investigate a unique database of global unlisted infrastructure deals and conclude that the desired characteristics of stable long-term and inflation linked returns have yet to be proven 
empirically. They argue that infrastructure deals are highly levered, and returns largely driven by market and political risk. DeFrancesco et al. (2011) find some evidence of excess returns in unlisted Australian infrastructure but rely on a small sample.

In terms of inflation hedging ability, Armann and Weisdorf (2008) and Martin (2010) find a positive correlation between infrastructure returns and inflation. On the other hand, Bitsch et al. (2010), using global unlisted infrastructure data, find no evidence of inflation hedging. Here we update the data used by Newell and Peng (2007, 2008) and propose a model that caters for additional style factors.

\section{The Model}

\subsection{Market factors}

Investment in infrastructure represents an allocation to equities, with a large asset base (high book-to-price ratio) and low but stable earnings growth, and thus can be priced using a number of style biases (or beta factors) and a risk-adjusted excess return (equation (1)). In the US, style tilts can be captured using the Fama and French (1993) SMB (Small minus Big stocks) and HML (High minus Low book-to-price stocks) factors. ${ }^{3}$ For Australia, we use the ASX Small Ordinaries returns minus the ASX 100 returns to proxy SMB, and the BMI Value minus BMI Growth index returns to approximate HML. The ASX Small Ordinaries index represents the stocks in the ASX 300, excluding the 100 largest stocks (which are captured in the ASX 100 index). The BMI (Broad Market Indices) are created by S\&P. All indices are market capitalisation weighted and these factors are measurable, interpretable and tradeable. Equation (1) presents the standard Fama-French model.

\footnotetext{
${ }^{3}$ Data can be downloaded from http://mba.tuck.dartmouth.edu/pages/faculty/ken.french/data_library.html
} 


$$
R_{i t}-R_{f t}=\alpha_{i}+\beta_{i, m}\left(R_{m, t}-R_{f t}\right)+\beta_{i, s} * S M B_{t}+\beta_{i, v} * H M L_{t}+\varepsilon_{i t}
$$

where $R_{i t}$ is the rate of return of asset class $i$ at time $t, R_{f t}$ is the risk-free rate at time $t$ and $\alpha_{i}$ is the intercept, or the risk-adjusted excess returns. In terms of factor exposure, $\left(R_{m, t}-R_{f t}\right)$ represents the equity risk premium, and $\beta_{i, m}$ measures the sensitivity of excess returns of the asset class to the equity risk premium. $S M B_{t}$ is the differential return between smaller and larger capitalised companies, and $H M L_{t}$ is the differential return between high and low book-to-price companies with sensitivities $\beta_{i, s}$ and $\beta_{i, v}$ respectively, $\varepsilon_{i t}$ is the error (residual) portion or the return not related to the other factors at time $t$, with an expected value of zero and variance described in Section 3.5.

\subsection{Illiquidity}

Serial correlation in returns may be high in illiquid, unlisted asset classes, where valuations for alternative assets can be appraisal-based rather than transaction-based since a lack of a tradable market for the underlying assets means that appraisers rely on previous valuations as an anchor point for current valuations. Somewhat surprisingly, we find no evidence for serial correlation in returns to Australian unlisted infrastructure in our dataset. ${ }^{4}$ Also surprising is that Australian unlisted infrastructure funds are open ended and offer monthly unit pricing, despite the funds themselves being invested in a small number of highly illiquid assets valued on a quarterly or annual basis. In reality, redemption tends to be at "best endeavours"-

\footnotetext{
${ }^{4}$ We suggest four types of noise reduce serial correlation. The first lies in the accrual of income into the monthly unit pricing. The second is changes in foreign currency values which create translation effects for unhedged overseas assets. The third is that some infrastructure managers allocate a portion of their funds to listed infrastructure assets. The fourth lies in the Discounted Cash Flow (DCF) valuation process. This method offers users a large number of input parameters for adjustment, such as bond yields, traffic growth rates, utilisation rates and assumed equity betas. Such valuation noise can reduce the serial correlation in returns.
} 
that is, within 12 months of receiving a redemption notice, and at the manager's discretion.

\subsection{Protection in down markets}

It is important to understand the defensive abilities of infrastructure during periods of market stress. To test market timing ability, Treynor and Mazuy (1966) include a quadratic term in the market excess return since returns to defensive assets are expected to fall less than the market during times of stress. Equation (2) extends equation (1) to include the market timing component $\left(R_{m t}-R_{f t}\right)^{2}$ where a significant positive coefficient $\left(\beta_{i, \text { timing }}\right)$ suggests positive market timing ability.

$R_{i t}-R_{f t}=\alpha_{i}+\beta_{i, m}\left(R_{m, t}-R_{f t}\right)+\beta_{i, s} * S M B_{t}+\beta_{i, v} * H M L_{t}+\beta_{i, \text { timing }}\left(R_{m t}-R_{f t}\right)^{2}+\varepsilon_{i t}$

\subsection{Inflation hedging abilities}

Investors allocate to infrastructure because of its perceived inflation hedging abilities (Armann and Weisdorf, 2008; Martin, 2010). Here we measure sensitivity to inflation expectations by comparing infrastructure returns with returns to US and Australian inflation-linked bonds (also known in the US as Treasury Inflation Protected Securities, or TIPS), using the Barclays US TIPS index and the UBS Australian Inflation Linked bond index, which are liquid and tradeable and thus offer a direct, monthly pricing relationship. Formula (3) extends formula (1) with an inflation factor.

$$
R_{i t}-R_{f t}=\alpha_{i}+\beta_{i, m}\left(R_{m, t}-R_{f t}\right)+\beta_{i, s} * S M B+\beta_{i, v} * H M L+\beta_{i, \text { inflation }} * T I P S+\varepsilon_{i t}
$$


A significant positive coefficient $\left(\beta_{i, \text { inflation }}\right)$ suggests inflation hedging ability where TIPS represents the inflation premium, or the returns on Treasury Inflation Protected Securities (TIPS) for the US (or the UBS inflation-linked bond index for Australia), minus the relevant risk-free rate. ${ }^{5}$

\subsection{Variance equation}

We model conditional heteroskedasticity and non-linearities in the errors $\varepsilon_{i t}$ using maximum likelihood estimation and the GJR-GARCH approach (Glosten et al., 1993). The GJR-GARCH model captures asymmetric conditional volatility $h_{i t}$ via an indicator term $I_{t-1}$ in the GARCH equation:

$$
h_{i t}=\gamma_{0}+\gamma_{1} \varepsilon_{i, t-1}^{2}+\gamma_{2} h_{i, t-1}+\gamma_{3} \varepsilon_{i, t-1}^{2} I_{t-1}
$$

where $I_{t-1}=0$ if $\varepsilon_{i, t-1} \geq 0$, and $I_{t-1}=1$ if $\varepsilon_{i, t-1}<0$.

In this case, $\gamma_{0}$ is a constant intercept impacting the long run unconditional volatility, $\gamma_{1}$ is a weighting to the previous period's squared shock $\varepsilon_{i, t-1}^{2}, \gamma_{2}$ is a weighting to the previous period's predicted volatility $h_{i, t-1}$ and $\gamma_{3}$ is a sensitivity to negative return shocks $\varepsilon^{2}{ }_{i, t-1} I_{t-1}$. In our model, we use $\mathrm{t}$ rather than normal distributed errors in estimation to capture fat tails. The degrees of freedom for the t-distribution are provided in Tables 3, 4 and 5.

\section{The Data}

\subsection{Listed infrastructure}

\footnotetext{
${ }^{5}$ For completeness we also tested infrastructure inflation hedging abilities directly by using CPI. We obtain similar results.
} 
The UBS infrastructure performance series used in this study are free float-adjusted, market capitalisation-weighted total return indices covering both the listed infrastructure and utilities sectors. The UBS indices are widely considered to be the most comprehensive set of listed infrastructure indices available and remain the standard benchmark for infrastructure managers worldwide. Table 1 contains a list of the available UBS infrastructure indices.

\section{$<$ INSERT TABLE 1 >}

\subsection{Australian unlisted infrastructure}

Mercer provided a unique, net-of-fees return data series for ten unidentified Australian unlisted infrastructure managers, representing 105 underlying assets worth A $\$ 11.1$ billion and covering some of the largest infrastructure managers in Australia. The largest manager comprises 25 assets, worth $\mathrm{A} \$ 5.5$ billion or 50 per cent of the total combined assets. The managers do not distinguish between pure infrastructure (non-utility assets such as toll roads, airports or railroads) and utility assets. In other words, most infrastructure funds hold both types of assets. Aggregating by summing the value of all underlying projects for each manager shows that utilities comprise 59 per cent of the underlying assets in our sample. The managers have domestic and international investments: 43 per cent of assets are in Australia, 21 per cent are in the UK, 19 per cent are in the US and 17 per cent are in the rest of the world. We do not know how much is invested on an unhedged basis, and so currency fluctuations may impact reported returns. While the return data provided by the managers extends back to January 1995, the collection of data on the assets inside the funds has only begun recently (2010), and we do not have access to historic asset values. Thus, we opted to create an equally weighted (rather than asset weighted) index to capture the performance of the Australian unlisted infrastructure sector. In the Mercer data set, 
survivorship bias is minimised as we are not aware of any funds being deleted for poor performance. In terms of selection bias, these funds by no means represent a complete list of the infrastructure opportunities, and some funds also choose not to participate in the Mercer database. However, it should also be acknowledged that not many infrastructure funds in Australia have a long data history comparable to the funds included in the Mercer data set. Thus we suggest the Mercer data set offers an adequate representation of the Australian unlisted infrastructure history.

\section{Empirical Results}

\subsection{Descriptive statistics}

Based on data availability we have selected indices from Table 1 that are available over the period from 1995 to 2009. The descriptive statistics are shown in Table 2.

\section{$<$ INSERT TABLE 2 >}

As can be seen from Table 2, all infrastructure sectors created excess returns over the risk-free rate over the period from 1995 to $2009 .{ }^{6}$ Listed infrastructure exhibits much higher volatility and also a higher beta to equity markets than listed utilities. Many sectors also exhibit a negative skew and positive kurtosis, suggesting a returns profile similar to a written call option and/or the use of leverage. ${ }^{7}$ No sector returns show significant first order autocorrelation.

\subsection{Factor model estimation results}

\footnotetext{
${ }^{6}$ In table 2 the total return for the combined Australian listed infrastructure and utilities index lies below the total returns reported for the separate listed infrastructure and listed utility indices, despite the index being a weighted average. We verified with UBS Australia that the data and calculations employed are correct. At every point in time a combined index is created as a weighted composite of the subindices. The low return is a function of time-varying weights. The weight in listed infrastructure varied from 10 per cent at the start of the period (when infrastructure outperformed utilities) to 50 per cent by the end of the period (when infrastructure underperformed utilities).

${ }^{7}$ It is quite possible the lack of negative skew in Australian unlisted is more a function of the valuation process than a reflection of the fundamentals of the actual asset class.
} 


\section{$<$ INSERT TABLE $3>>$}

Table 3 shows estimation results for the Fama-French factor model of excess returns to US listed infrastructure, to Australian listed infrastructure and utilities, and to Australian unlisted infrastructure and utilities. We estimate significant equity betas $\left(\beta_{m}\right)$ for US infrastructure (1.35) and Australian infrastructure (0.67) and more defensive equity betas for listed utilities, between 0.47 and 0.57 . Four of the sectors display a positive significant style tilt towards small stocks $\left(\beta_{s}\right)$, while for the other three the tilt is negative but insignificant. The majority of the sectors favour value stocks $\left(\beta_{v}\right)$, with the notable exception of US infrastructure, which is dominated by communication (growth) stocks with a low fixed asset base.

There are persistent GARCH effects $\left(\gamma_{2}\right)$ but no sign of significant asymmetries $\left(\gamma_{3}\right)$. With the adjusted $\mathrm{R}^{2}$ varying between 0.18 and 0.34 the model provides a reasonable fit for listed infrastructure and utility sectors but for Australian unlisted infrastructure and utilities the model provides a very poor fit $\left(\mathrm{R}^{2}\right.$ of 0.01$)$. Interestingly, we do not find evidence of leverage effects $\left(\gamma_{3}\right)$, but we do find strong evidence of GARCH effects, even for unlisted infrastructure. Under a strict appraisal based valuation process, one would not expect to find GARCH effects, but constant return volatility. The GARCH effects suggest unlisted infrastructure appraisal processes are influenced by market factors. The proportion of excess return unexplained by the factor model raises the possibility of a regulatory risk premium, which we discuss in Section 6.

\subsection{Defensive properties}

$<$ INSERT TABLE 4 >> 
Table 4 shows the performance of infrastructure and utility stocks during up and down equity markets. The negative coefficient for $\beta_{\text {timing }}$ in Table 4 is evidence of deteriorating performance for US utilities and Australian listed infrastructure during market downturns, although we note that this is not statistically significant. We conjecture that this is a function of the leverage employed by listed fund managers (in Australia), and also the high gearing of underlying assets.

\section{$<<$ INSERT FIGURE 1 >>}

Figure 1 graphs the performance of infrastructure assets during up and down equity markets and also the predicted forecast returns for the asset class as derived using equation (2). As can be seen, the relationship is concave rather than convex for US utilities and Australian listed infrastructure. The downward slope in the line indicates that a downturn in equity markets results in increasingly poor performance from US utility stocks, as well as Australian listed infrastructure stocks, and that during times of financial stress (negative equity markets), some types of infrastructure and utilities may not possess the desired defensive characteristics.

\subsection{Inflation hedging properties}

\section{$<$ INSERT TABLE $5>$}

Table 5 shows that US and Australian utility sectors have inflation hedging ability based on the sensitivity ( $\left.\beta_{\text {inflation }}\right)$ to inflation linked bonds (TIPS), and consistent with findings by Armann and Weisdorf (2008) and Martin (2010) for the US. However, pure infrastructure (non-utility) stocks show no evidence of inflation hedging: regulated utilities appear to have more ability to pass inflation increases to customers without much loss in demand. While energy generation and distribution assets can face relatively inelastic demand, the situation for non-utility assets may be different. 
Toll roads may experience a fall in traffic volume when tariffs are increased: there may be stickiness in prices resulting from money illusion as customers focus on nominal, as opposed to real price increases (Diamond et al., 1997).

\section{Pricing of regulatory risk}

\subsection{Regulated versus unregulated assets: introducing option based models}

Henisz and Zelner (1999, p.1) emphasise "the importance of regulatory risk in sectors characterised by large sunk costs, substantial economies of scale and highly politicised pricing, such as telecommunications and electricity generation". We argue that investors in infrastructure assets are exposed to two types of regulatory risk:

1. Investors in large infrastructure businesses with significant regulated energy or utility activities typically negotiate rates of return on equity (ROE) in the range of 10.0 to 15.0 per cent. Thus, from a fundamental perspective, regulatory risk limits tariff increases, which can be viewed as analogous to the government exercising an implicit (out of the money) call option. Investors are effectively allowed to retain an asset with monopolistic characteristics (as Dimasi, 2010, notes through either the provision of essential services or monopolies of scale), but in return forego the possibility of supernormal profits that would cause welfare losses.

2. Governments can act as 'lender of last resort' to infrastructure projects and may support the private sector partner during times of distress if the infrastructure services are deemed essential to the community. Thus, investors effectively hold a put option to sell assets back to the government if the asset price declines. 
Thus, we derive the following equation for the returns of regulated assets:

$$
R_{\text {regulated asset }}=R_{\text {unregulated asset }}+P_{\text {regulatory call option }}-P_{\text {regulatory put option }}
$$

where $P_{\text {regulatory call option }}$ reflects the receipt of the monopoly premium compensating for the regulatory cap, and $P_{\text {regulatory }}$ put option reflects the implicit premium paid for regulatory assistance on the downside. This payoff profile is shown in Figure 2.

$<$ INSERT FIGURE 2 >

\subsection{Regulated versus unregulated assets: initial comparison}

$$
<\text { INSERT TABLE } 6 \text { >> }
$$

Table 6 shows comparative performance of the US and Australian markets. The returns on a direct investment in the listed infrastructure and utility sectors in the US and Australia are shown in row 1, column A, while an investment in unregulated assets is proxied by the broad market index in row 1, column H. It can be seen that the regulated assets (the infrastructure and utility sector) outperform the unregulated assets (the broad market index) in both the US and Australia over the period investigated. The premium is 0.2 per cent per annum in the US (7.9 minus 7.7 per cent), and 6.0 per cent in Australia (16.2 minus 10.2 per cent). On this basis, an investment in regulated assets in the infrastructure and utilities sector seems attractive.

\subsection{Regulated versus unregulated assets: implementing the ROE cap}

We now evaluate the performance of the regulated asset assuming that the government has initiated a cap on the return on equity of the unregulated asset represented in column $\mathrm{H}$ (the S\&P 500, or the ASX 300). Row 10, columns B to G 
show premiums of 10 to 15 per cent imposed on the unregulated asset. Refer to Figure 2 for more details on how the premium received $\left(P_{\text {regulatory call option }}\right)$ is derived from a calibration in the strike price. Using the first part of equation (5), we then find

$$
R_{\text {regulated asset }}=R_{\text {unregulated asset }}+P_{\text {regulatory call option }}
$$

Row 1, columns B to $G$ show the returns to the covered call strategies. As can be seen, in the US the regulated assets (row 1, column A) now underperform the covered call strategies (row 1, columns B to G). In Australia, the regulated assets still outperform the covered call strategies. Row 3, columns B to G show that in both the US and Australia the covered call strategy increases the reward to risk ratio. In addition, row 9, columns $B$ to $G$ suggest covered call strategies exhibit a similar equity beta to regulated assets (0.6 to 0.7$)$. By subtracting the returns in row 1 in columns $\mathrm{B}$ to $\mathrm{G}$ from column $\mathrm{H}$ we can derive the additional return (premium) received for selling the call option. We find in the US the premium ranges between 1.6 and 2.2 per cent per annum (row 12, columns B to G), based on an assumed ROE cap range of 10 to 15 per cent. In Australia, the additional premium is higher at between 3.6 and 4.1 per cent.

\subsection{Regulated versus unregulated assets: the cost of downside protection}

In the previous discussion we did not consider the potential of government intervention on the downside (hence the term "no floor" was used in row 12). We now assume the investor receives access to an implicit government put option, where, in case of distress, the government has an incentive to subsidise or rescue infrastructure projects that are too large or important to fail. We examine three possible scenarios: 
no floor (no intervention expected), distressed intervention (intervention expected after asset prices decline by 75 per cent) and regular intervention (intervention expected after asset prices decline by 50 per cent). As can be seen in rows 12 to 14 , buying a put option reduces the premium received from selling the call. The cost of the implicit put reduces the net premium received by around 1 per cent in both the US and Australia. Overall, we find that in the US regulated assets (row 1, column A) outperformed unregulated assets (row 1, column H) by 0.2 per cent. However, after taking into account the implicit regulatory restrictions, this is no longer the case. In Australia, we find that regulated assets (row 1, column A) outperform unregulated assets (row 1, column $\mathrm{H}$ ) by 6.0 per cent and continue to do so even after implementing the option based strategies. In other words, whereas in the US an investor would have been better off investing in a combination of the unregulated assets with option protection, in Australia, investors would have been better off investing in the infrastructure and utilities sector directly.

However, the aforementioned option based model does not take into account that: a) option based strategies with specific strike prices need to be tailor-made by investment banks and customised in the Over The Counter (OTC) market, thereby exposing investors to counterparty credit risk b) infrastructure was shown to have some inflation hedging ability and c) some transaction costs may be involved. For completeness, we compare the net premiums received from the option program to listed option return indices for some of the available strike prices. We find the difference between our theoretical returns and the listed product equivalent to be minimal. In our strategies the transaction costs are reduced because the options are held until maturity, that is, no intra-month trading needs to take place. 


\section{A synthetic real defensive asset}

We propose a synthetic approach that combines the desired defensive and inflation hedging characteristics of infrastructure with a proxy for the regulatory risk premium. The synthetic approach relies solely on exchange-traded instruments. We use a covered call to capture the regulatory risk premium and defensive and inflation hedging characteristics via an investment in inflation-linked bonds.

1. Covered call strategy. The BXM index, provided by the Chicago Board Options Exchange (CBOE) simulates continuous call writing for one month out of the money calls on the S\&P 500. It is liquid and readily tradeable. For Australia we use a comparable index (XBW), which involves writing of nearby, just out of the money three-month call options. ${ }^{8}$

2. Put option strategy. A floor on the portfolio is implemented through an investment in a bond portfolio. This bond portfolio consists of Treasury Inflation Protected Securities (TIPS), which are government guaranteed. The investment is made through the Barclays US TIPS index or the UBS Australia Inflation Linked bond index. ${ }^{9}$

We follow a dynamic updating process to create the synthetic portfolio. The period from January 1995 to December 1997 is used to set the initial (in-sample) factor weights based on regressing listed infrastructure and utility returns against the covered

\footnotetext{
8 For BXM data refer http://www.cboe.com/micro/bxm/\#historical. For XBW data refer http://www.asX.com.au/products/indices/types/buy_write/history.htm.

${ }^{9}$ The investment can be made through direct securities, passive index funds (unlisted funds) or Exchange Traded Funds (listed funds).
} 
call index and the inflation linked bond (TIPS) index as risk factors. This period is chosen to reflect at least 30 monthly data points for the initial weight estimates. The factor weights are then dynamically adjusted as the next monthly (out-of-sample) data point becomes available and the regression is updated using the lengthened lookback period. The dynamic weights are used to determine the replicated returns for the subsequent month. This results in an allocation which converges to around a 50 per cent dollar weight to the covered call index and 50 per cent to TIPS. The covered call allocation creates the exposure to the equity and regulatory risk premium while the allocation to TIPS creates the desired inflation hedging characteristics and floor.

\subsection{Return characteristics of the synthetic asset}

\section{$<$ INSERT TABLE $7>>$}

Table 7 compares the outcome from a direct investment in infrastructure and a synthetically created exposure for both the US and Australian markets. The synthetic asset has a lower equity beta (0.3) and higher inflation hedging beta (0.5 to 0.7$)$ than the direct investment, both desirable characteristics. The synthetic asset has a higher return than the direct investment in the US but a lower return in Australia. ${ }^{10}$ Even in Australia, the synthetic asset may still generate comparable results to the direct investment in the long run, provided the excess returns generated by the direct investment are on a declining trend. We show the trend in historical excess returns for the direct investment using the rolling three-year alpha in Figure 3.

$$
<<\text { INSERT FIGURE } 3 \text { >> }
$$

\footnotetext{
${ }^{10}$ It can be argued that over the period unique factors were at play in Australia (which were absent in the US) which overstate the expected return that one can expect from direct investment. These include a high concentration of highly geared listed infrastructure funds. In addition, for a period of time, assets could be purchased at a discount from distressed state governments such as the state of Victoria. These conditions may not occur again in the future, as a) the gearing level of infrastructure funds has reduced and b) competition for the limited number of suitable projects domestically has increased.
} 
Figure 3 suggests there has indeed been a reduction in excess returns generated by Australian infrastructure and utilities in recent periods. Biais et al. (2009) demonstrate how in equilibrium, after an initial period of success, an industry grows, attracting human and financial capital, while rents of managers increase. This increase in rents undermines the net returns obtained by investors and can eventually make incentives so expensive that excessive risk taking prevails in the last part of the cycle. As noted earlier, we observed this sequence of events to occur for Australian infrastructure managers such as Macquarie Infrastructure Group and Babcock and Brown.

\subsection{Risk characteristics of the synthetic asset}

\section{$<$ INSERT FIGURE 4 >}

Figure 4 shows the historical maximum drawdown charts for the US and Australian direct investment compared to the synthetic asset. As can be seen the drawdown for the synthetic asset is much less than it is for direct investment in both the US and Australian markets. Thus, once again, the synthetic asset offers superior defensive characteristics compared to the direct investment. As a final test of the robustness of the synthetic asset compared to the direct investment in infrastructure we employ a bootstrap to simulate both direct investment and synthetic asset returns. We measure the defensive abilities of the direct investment and the synthetic asset under simulated conditions. The results are shown in Table 8.

$$
<\text { INSERT TABLE } 8>>
$$

Table 8 indicates that the synthetic asset outperforms direct investment in both the US and Australia in terms of VaR and Expected Shortfall over the simulated periods. 


\section{Conclusion}

We confirm that excess returns exist in both US and Australian infrastructure investment suggesting additional factors (e.g. a regulatory risk premium) have a role to play in explaining the variation in infrastructure returns. In addition, we confirm findings by Armann and Weisdorf (2008) and Martin (2010) that both US and Australian infrastructure investments offer some inflation protection. However, we find inflation hedging is limited to the utility sector, but not present in the non-utility infrastructure sector. We compare the historically achieved excess return to the required regulatory premium using a comparable option based model (Table 6). We find that in the US, investors were better off investing in option based strategies. In Australia, however, the historically achieved returns in the infrastructure sector exceeded those from the option based strategy. In addition, we suggest how a synthetic portfolio consisting of exchange traded covered calls and inflation linked bond portfolios can offer comparable defensive and inflation hedging characteristics.

The returns to unlisted infrastructure could be further investigated. Bitsch et al. (2010), based on a study of global unlisted infrastructure deals, suggest returns to be highly correlated to equity markets. ${ }^{11}$ Yet, for Australian unlisted infrastructure we find no sensitivity to the public equity markets at either the aggregate index level or individual manager level. In addition, we expect indices on illiquid assets to embed serial correlation. While we earlier explained that exposure to accrued income, foreign exchange movements, listed assets and the DCF valuation methodology may create noise around unit pricing, this topic can be further researched, subject to data availability.

\footnotetext{
${ }^{11}$ Furthermore, literature suggests that investments in unlisted firms, whether direct or through active managers, underperform investments in listed firms, refer Nielsen (2011) and Phalippou (2009).
} 
Finally, Bond et al. (2007) as well as Dechant and Finkenzeller (2011) suggest real estate has superior defensive characteristics to infrastructure. At the same time Newell and Peng (2007) find correlations between infrastructure and real estate have increased over time, suggesting some of the unique diversification benefits of infrastructure are disappearing. From an institutional investor's perspective it will be interesting to see if infrastructure can eventually replace real estate in overseas institutional portfolios to the same extent as it has in Australia.

\section{Appendix. Methods of investing in infrastructure}

This appendix describes the methods of investing in infrastructure. Infrastructure companies can be listed on the stock exchange or unlisted and traded in private markets. Investments can be made by directly buying the listed companies/assets or indirectly by investing through a fund. Infrastructure funds themselves can also be either listed or unlisted. Source: Inderst (2009) and company websites.

Indirect investment

Direct investment

\begin{tabular}{|c|c|c|}
\hline \multirow[t]{3}{*}{$\begin{array}{l}\text { Listed } \\
\text { markets }\end{array}$} & $\begin{array}{l}\text { Indirect investment refers to } \\
\text { investment through fund managers } \\
\text { that invest in listed infrastructure }\end{array}$ & $\begin{array}{l}\text { Direct investment refers to infrastructure } \\
\text { companies or funds listed on the stock } \\
\text { exchange. }\end{array}$ \\
\hline & $\begin{array}{l}\text { companies. } \\
\text { In Australia this has been } \\
\text { particularly popular with retail } \\
\text { investors who prefer the daily } \\
\text { liquidity. }\end{array}$ & $\begin{array}{l}\text { Listed infrastructure companies (including } \\
\text { utilities) account for around 5\% of the } \\
\text { global stock markets. An example of such } \\
\text { a company is AGL Energy. } \\
\text { http://www.agl.com.au/ }\end{array}$ \\
\hline & $\begin{array}{l}\text { An example of an unlisted } \\
\text { infrastructure fund manager that } \\
\text { invests in listed infrastructure } \\
\text { companies is RARE. } \\
\text { http://www.rareinfrastructure.com/ }\end{array}$ & $\begin{array}{l}\text { Listed infrastructure funds invest in } \\
\text { unlisted assets. Listed infrastructure funds } \\
\text { are most common in Australia where they } \\
\text { account for } 50 \% \text { of the infrastructure and } \\
\text { utilities sector (which in itself represents } \\
5 \% \text { of the Australian market } \\
\text { capitalisation). An example of a listed } \\
\text { infrastructure fund over the period } \\
\text { investigated is Intoll (formerly Macquarie } \\
\text { Infrastructure Group, subsequently } \\
\text { restructured and acquired by the Canada } \\
\text { Pension Plan Investment Board). } \\
\text { http://www.intoll.com/ }\end{array}$ \\
\hline
\end{tabular}


Unlisted markets
Indirect investment in unlisted assets has been popular for pension funds in Australia, through specialist fund managers which are unlisted themselves, such as Industry Funds Management (IFM).

Investments for funds tend to be concentrated in 10 to 15 large investments. http://www.industryfundsmanagem
Some of the bigger Canadian and Dutch pension plans have started to invest directly. They are often co-investors with specialist funds, and thereby hope to build up the internal expertise in-house over time. For example, in Canada, the Ontario Municipal Employees Retirement System (OMERS) has invested in infrastructure through its subsidiary Borealis Infrastructure, set up in 1998. http://www.borealis.ca

ent.com/

\section{References}

Armann, V. and Weisdorf, M.A., 'Hedging inflation with infrastructure assets', in Benaben, B., and S. Goldenberg, Inflation Risks and Products: The Complete Guide, Risk Books, 2008, pp. 111-126.

Biais, B., Rochet, J.C., and Woolley, P., 'Rents, learning and risk in the financial sector and other innovative industries', Working Paper (Paul Woolley Centre, Toulouse School of Economics, 2009).

Bitsch, F., Buchner, A., and Kaserer, C., 'Risk, return and cash flow characteristics of infrastructure fund investments', EIB Papers, Vol. 15(1), 2010, pp. 106-136.

Bond, S.A., Hwang, S., Mitchell, P., and Stachell, S.E., 'Will private equity and hedge funds replace real estate in mixed-asset portfolios? Not likely', Journal of Portfolio Management - Special Real Estate Issue, Vol. 33, 2007, pp. 74-84.

Chan, K.C., Chen, C.R., and Lung, P.P., 'Business cycles and net buying pressure in the S\&P 500 futures options', European Financial Management, Vol. 16(4), 2010, pp. 624-657.

Dechant, T., Finkenzeller, K., and Schäfers, W., 'Infrastructure: a new dimension of real estate?', Journal of Property Investment and Finance, Vol. 28(4), 2010, pp. 263-274.

Dechant, T., and Finkenzeller, K., 'Real estate or infrastructure? Evidence from conditional asset allocation', Working Paper (University of Regensburg, 2010).

DeFrancesco, A., Newell, G., and Peng, H.W., 'The performance of unlisted infrastructure in investment portfolios', Journal of Property Research, Vol. 28(1), 2011, pp. 59-74.

Diamond, P., Shafir, E., and Tversky, A., 'Money illusion', Quarterly Journal of Economics, Vol. 112(2), 1997, pp. 341-374.

Dimasi, J., 'Evaluating infrastructure reforms and regulation', Working Paper (Australian Competition and Consumer Commission, 2010).

Fama, E.F., and French, K.R., 'Common risk factors in the returns on stocks and bonds', Journal of Financial Economics, Vol. 33(1), 1993, pp. 3-56.

Glosten, L.R., Jagannathan, R. and Runkle, D.E., 'On the relation between the expected value and the volatility of the nominal excess returns on stocks', Journal of Finance, Vol. 48(5), 1993, pp. 1779. 1801.

Henisz, W.J., and Zelner, B.A., 'Political risk and infrastructure Investment', Working Paper (Wharton School - University of Pennsylvania, 1999).

Inderst, G., 'Pension fund investment in infrastructure', Working Paper (OECD, 2009).

Martin, G.A., 'The long horizon benefits of traditional and new real assets in the institutional portfolio', Journal of Alternative Investments, Vol. 13(1), 2010, pp. 6-29. 
Newell, G., and Peng, H.W., 'The significance of infrastructure in investment portfolios', Pacific Rim Real Estate Conference, Fremantle, 2007.

Newell, G., and Peng, H.W., 'The role of U.S. infrastructure in investment portfolios', Journal of Real Estate Portfolio Management, Vol. 14(1), 2008, pp. 21-33.

Nielsen, K.M., 'The return to direct investment in private firms: new evidence on the private equity premium puzzle', European Financial Management, Vol. 17(3), 2011, pp. 436-463.

Phalippou, L., 'Beware of venturing into private equity', Journal of Economic Perspectives, Vol. 23(1), 2009, pp. 147-166.

Treynor, J.L., and Mazuy, K., 'Can mutual funds outguess the market?', Harvard Business Review, Vol. 44(4), 1966, pp. 131-136. 


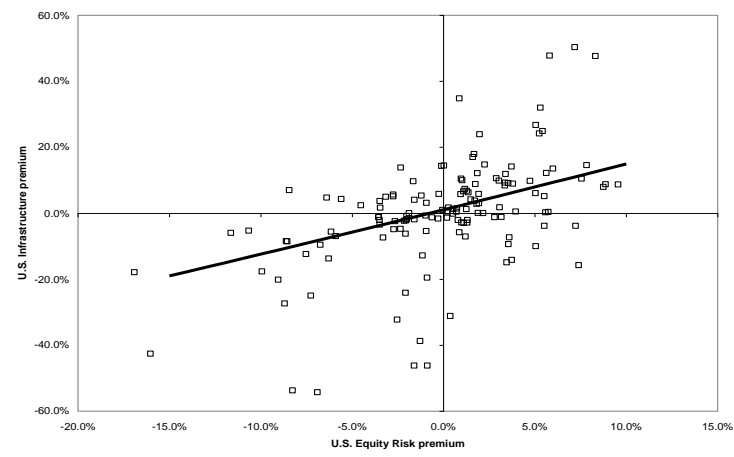

US infrastructure (1998-2009)

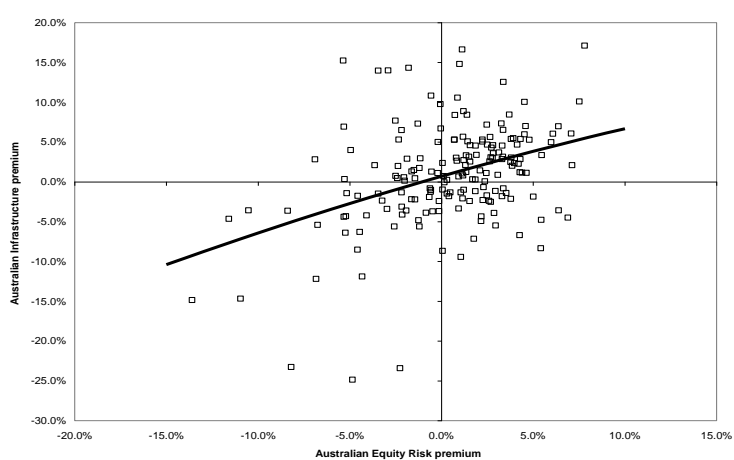

Australian infrastructure (1995-2009)

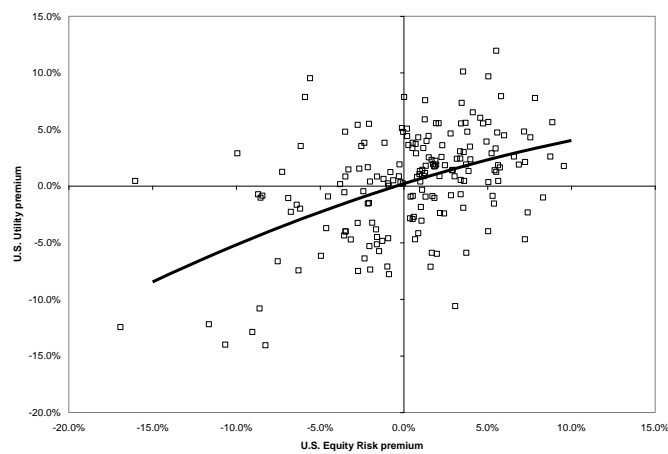

US utilities (1995-2009)

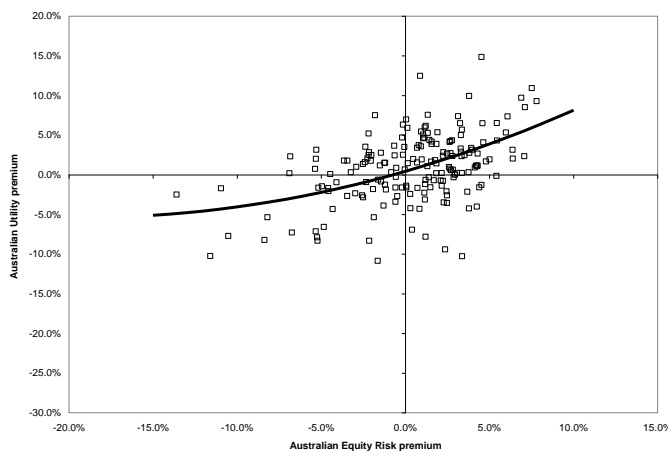

Australian utilities (1995-2009)

Fig. 1. Evidence of defensive abilities.

This figure presents an illustration of the defensive abilities of infrastructure and utilities under the Treynor and Mazuy (1966) model as presented by mean equation (2), $R_{i t}-R_{f t}=\alpha_{i}+\beta_{i, m}\left(R_{m, t}-R_{f t}\right)+$ $\beta_{i, s} * S M B_{t}+\beta_{i, v} * H M L_{t}+\beta_{i, \text { timing }}\left(R_{m t}-R_{f t}\right)^{2}+\varepsilon_{i t}$. The figure plots the observed asset returns on the yaxis versus the equity market returns on the $\mathrm{x}$-axis at each point in time. The predicted outcome from equation (2) is represented as the solid line. When equity market returns turn increasingly negative, under Treynor and Mazuy a convex solid line is expected, i.e. the forecast asset returns should fall less than the corresponding market returns. 


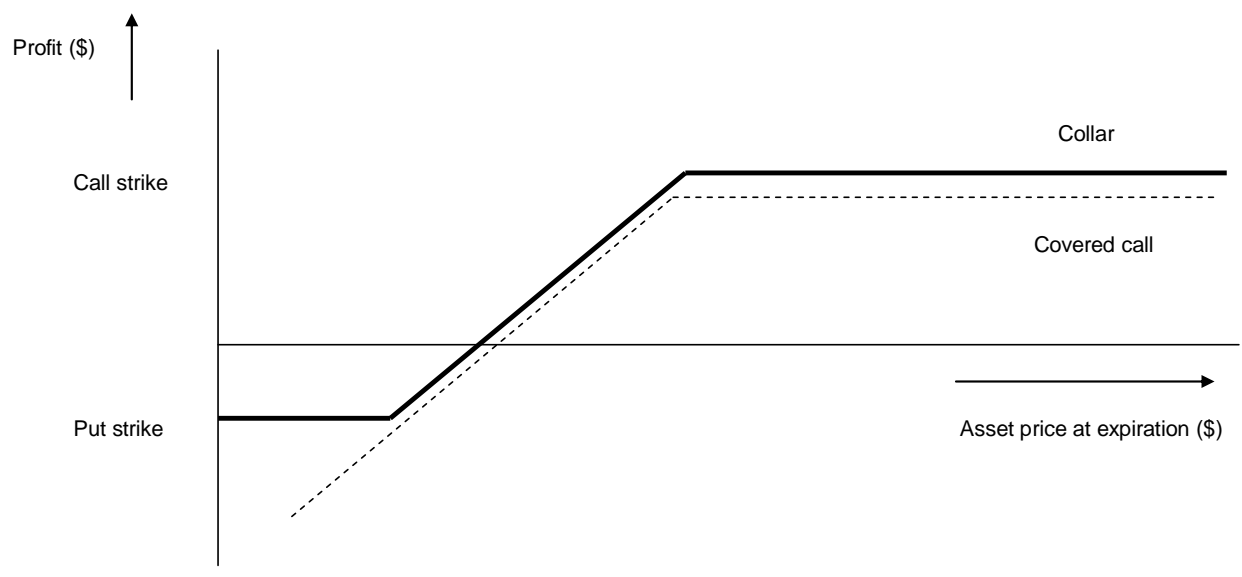

Fig. 2. Modelling the regulatory risk premium.

This figure presents the payoff diagram of a regulated asset. The option collar reflects the impact of government intervention on both the up and down side of an asset price and is established by buying a protective put while writing an out-of-the-money covered call. The maximum profit is reached at the strike price of the written call (the negotiated cap on the return on equity), while the maximum loss occurs at the strike price of the bought put (the level at which the government is likely to buy back the asset) if the asset is deemed to provide essential services to the community. The dotted line represents a covered call strategy, while the solid line represents the covered call combined with the bought put strategy. Chan et al. (2010) suggest the trading profits for selling options are higher during economic contraction periods than during expansion periods.

\section{Call options}

Evidence indicates that investors in large infrastructure businesses with significant regulated energy or utility activities require rates of return on equity (ROE) in the range of 10 to 15 per cent. For infrastructure, if $R O E_{\max }$ is the maximum allowed regulatory ROE, this is translated into a monthly call option sale with a strike price $K$ equal to $R O E_{\max } / 12$ in the US or a quarterly option sale with a strike price $K$ equal to $R O E_{\text {max }} / 4$ in Australia. For example, a 12 per cent limit on $R O E$ is proxied as selling an out of the money monthly call option with a 1 per cent (12 per cent divided by 12 months) premium. We assume that in the long run, the $R O E$ growth cap implies a profit growth limit, and thus a share price growth limit. In general the share price growth $(g)$ rate equals the retention rate $(r r)$ on profits times return on equity $(R O E)$, or $g=r r \times R O E$. Here we use total return indices with dividends reinvested, or $r r=1$ in which case $g=R O E$ (all profits are retained).

\section{Put options}

Put options are used to estimate the cost of government intervention after a decline in the asset value $S$ to a minimum floor $S_{\min }$, as infrastructure offers essential community services. The intervention floor $S_{\min }$ is translated into a monthly put option purchase with a strike price $K$ equal to $S_{\min } / 12$ in the US or a quarterly option purchase with a strike price $K$ equal to $S_{m i n} / 4$ in Australia. 


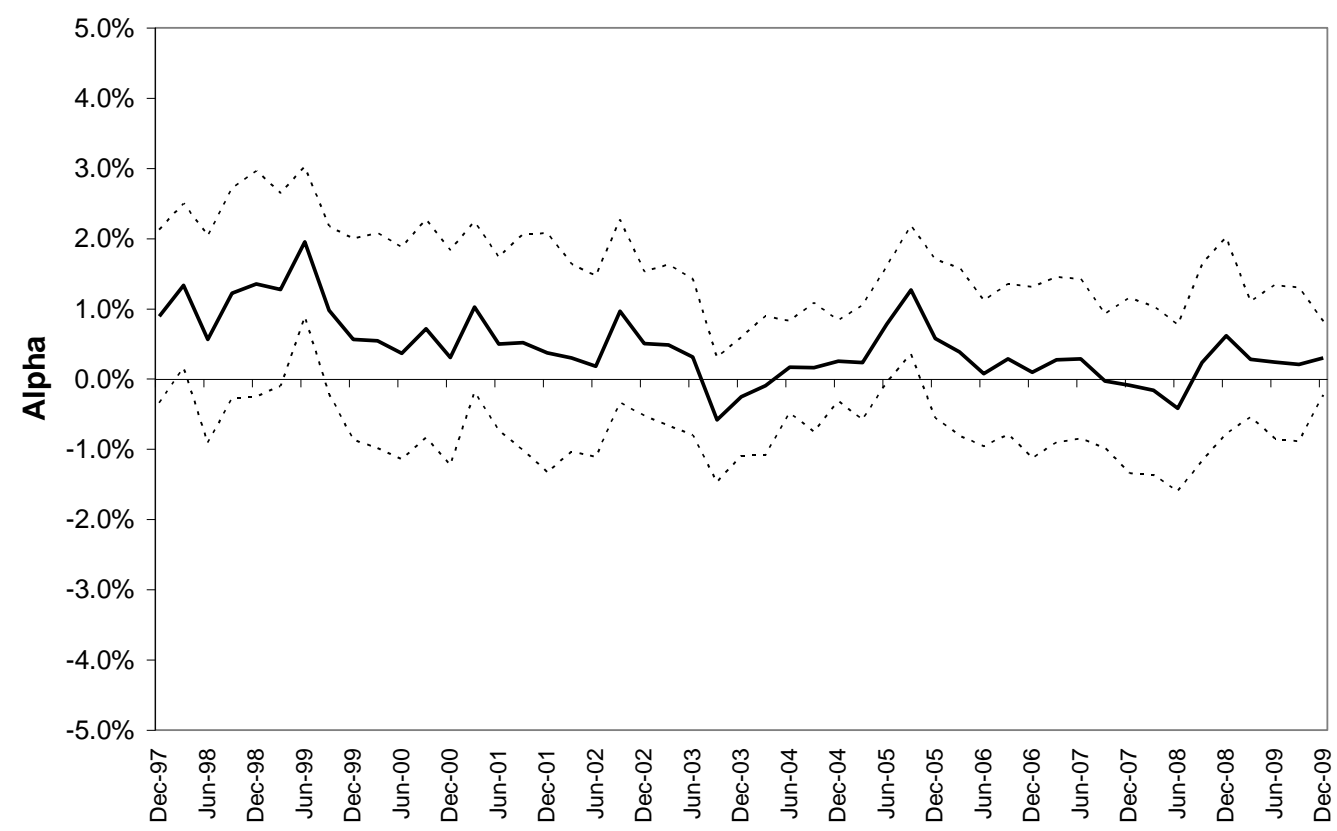

Fig. 3. Three-year rolling excess returns for 1997-2009 for the listed Australian infrastructure and utilities sector.

This figure presents the rolling three-year excess returns (alpha) based on mean equation (3) and variance equation (4),

$$
\begin{aligned}
& R_{i t}-R_{f t}=\alpha_{i}+\beta_{i, m}\left(R_{m, t}-R_{f t}\right)+\beta_{i, s} * S M B_{t}+\beta_{i, v} * H M L_{t}+\beta_{i, \text { inflation }} * T I P S+\varepsilon_{i t} \\
& h_{i t}=\gamma_{0}+\gamma_{1} \varepsilon_{i, t-1}^{2}+\gamma_{2} h_{i, t-1}+\gamma_{3} \varepsilon_{i, t-1}^{2} I_{t-1}
\end{aligned}
$$

Based on equation (3), excess returns are represented after accounting for equity risk, small cap and value style biases and inflation risk. 


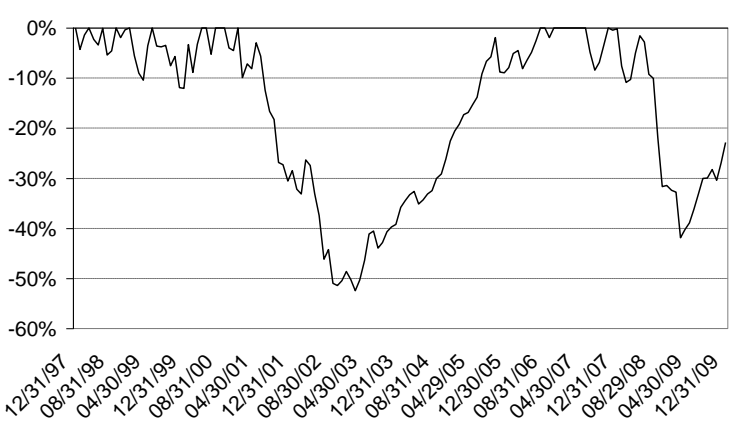

US - direct investment

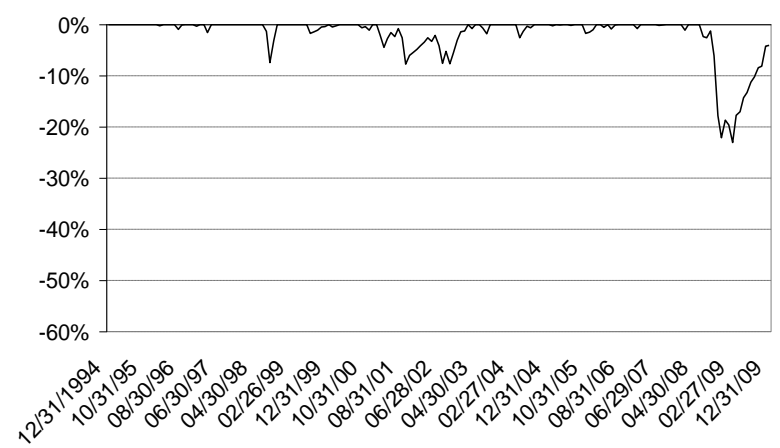

US - synthetic asset

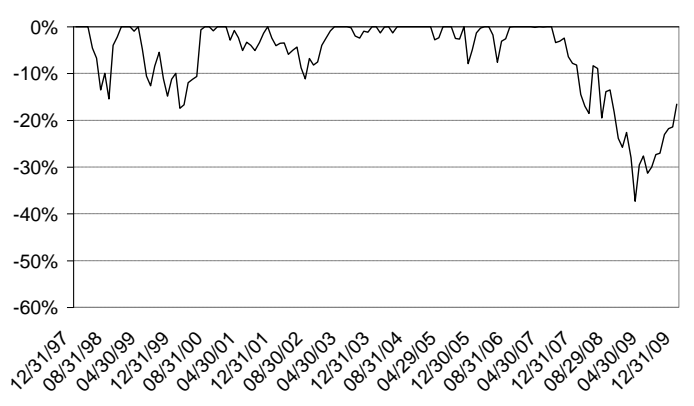

Australia - direct investment

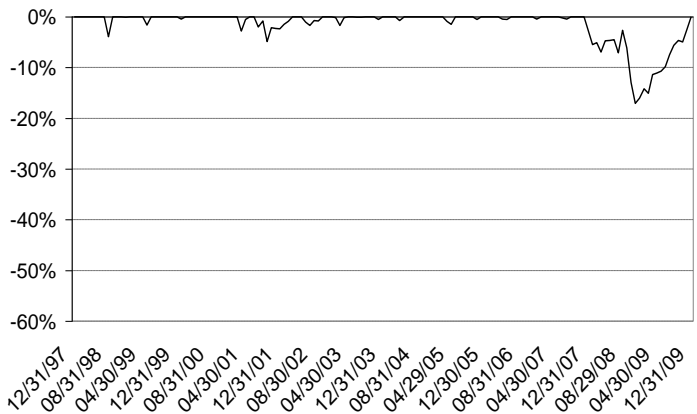

Australia - synthetic asset

Fig. 4. Maximum drawdown experience for direct investment compared to synthetic asset (1998-2009).

This figure presents out-of-sample drawdown charts, defined as the percentage loss that an asset incurs from its peak value to its lowest subsequent value. For example, an asset that halves in value before returning to its subsequent peak is deemed to have a maximum drawdown of 50 per cent. Drawdown charts are used to measure an asset's defensive ability. 


\section{Table 1}

\section{Overview of UBS infrastructure indices (monthly data is provided)}

This table presents relevant sub-indices of the UBS global infrastructure and utilities index, which covers over 200 stocks, with a 40 per cent weight to the U.S., 40 per cent to Europe and 20 per cent to Asia. Ninety per cent of the UBS global index comprises utility companies. Given the available data history and index constituents, we focus on the US and Australian sub-indices

As at December 2009, the US infrastructure and utilities index contained 89 companies with a total market capitalisation of US\$526.2 bn. The US index comprises 94 per cent utilities and has little pure (non-utility) infrastructure such as privatised communications, airports or toll roads. As such US subsectors are not provided by UBS. The number of US infrastructure stocks in the UBS index is limited to only three, all in the communication sector.

As at December 2009, The Australian index covered 15 companies with a combined value of A $\$ 50.5$ bn. The ratio of infrastructure stocks to utility stocks has declined to 37 per cent from a peak of 50 per cent following the default and restructuring of infrastructure stocks such as Macquarie Infrastructure Group and Babcock \& Brown after the Global Financial Crisis. For Australia, there is a concentration risk: the top three stocks (Origin, AGL and Transurban) account for 61 per cent of the combined index.

\begin{tabular}{|c|c|c|}
\hline Index & Date started & Description \\
\hline \multicolumn{3}{|c|}{ U.S. market (in USD) } \\
\hline $\begin{array}{l}\text { Infrastructure and } \\
\text { utilities }\end{array}$ & Jan 1990 & Combined infrastructure ( 6 per cent) and utilities ( 94 per cent) \\
\hline Infrastructure ${ }^{(1)}$ & Aug 1998 & $\begin{array}{l}\text { Concession, lease or freehold for transportation and } \\
\text { communication }\end{array}$ \\
\hline Utilities & Jan 1990 & Power generation, transmission and distribution \\
\hline - Power generation & Jan 2000 & $\begin{array}{l}\text { Involved in generation of electricity, including hydro and } \\
\text { renewable sources. }\end{array}$ \\
\hline $\begin{array}{l}\text { - Transmission / } \\
\text { Distribution }\end{array}$ & Jan 2000 & $\begin{array}{l}\text { Utility businesses exposed to transmission and distribution } \\
\text { assets (e.g. electricity transmission towers, pipelines, } \\
\text { distribution networks }\end{array}$ \\
\hline - Integrated Utilities & Jan 2000 & Vertically integrated electricity/gas companies \\
\hline \multicolumn{3}{|c|}{ Australian market (in AUD) } \\
\hline $\begin{array}{l}\text { Infrastructure and } \\
\text { utilities }\end{array}$ & Jan 1995 & $\begin{array}{l}\text { Combined infrastructure ( } 37 \text { per cent) and utilities ( } 63 \text { per } \\
\text { cent) }\end{array}$ \\
\hline Infrastructure & Jan 1995 & $\begin{array}{l}\text { Concession, lease or freehold for transportation and } \\
\text { communication }\end{array}$ \\
\hline - Airports & April 1997 & $\begin{array}{l}\text { Revenue from collection of aircraft landing fees, terminal fees } \\
\text { and revenue from airport retail, property and parking }\end{array}$ \\
\hline - Communication & Feb 2003 & $\begin{array}{l}\text { Revenue from communication usage fees (e.g. broadcast, } \\
\text { mobile towers, satellites, fibre optics) }\end{array}$ \\
\hline - Toll Roads & Jan 1995 & Revenue from collection of tolls \\
\hline Utilities & Jan 1995 & Power generation, transmission and distribution \\
\hline - Integrated Utilities & Jan 1995 & Vertically integrated electricity/gas companies \\
\hline - Power generation & Jan 1995 & $\begin{array}{l}\text { Involved in generation of electricity, including renewable } \\
\text { water. }\end{array}$ \\
\hline $\begin{array}{l}\text { - Transmission / } \\
\text { Distribution }\end{array}$ & Jan 1997 & $\begin{array}{l}\text { Utility businesses exposed to transmission and distribution } \\
\text { assets (e.g. electricity transmission towers, pipelines, } \\
\text { distribution networks }\end{array}$ \\
\hline
\end{tabular}


Table 2

Descriptive statistics of the infrastructure industry (1995-2009)

This table presents descriptive statistics of the industry based on monthly data from January 1995, or since inception date, to December 2009 (a total of 180 observations). The data represents log returns in USD for the US or AUD for Australia based on the UBS indices described in Table 1. The total return is annualised by multiplying monthly results by 12. Excess returns are calculated against the three-month risk free rate (the 90 day US Treasury or Australian Bank Bill rate). The standard deviation is annualised by multiplying the monthly standard deviation by the square root of 12. Best month represents the month with the highest monthly return. Worst month represents the month with the lowest monthly return. Beta is measured by calculating the slope of the strategy returns against the S\&P 500 or ASX 300 index. Skew and kurtosis represent the skew and kurtosis of the monthly returns. Liquidity refers to the first order serial correlation of the monthly returns. Data for U.S. listed infrastructure is available from August 1998 onwards.

\begin{tabular}{|c|c|c|c|c|c|c|c|c|c|}
\hline U.S. (in USD) & $\begin{array}{l}\text { total } \\
\text { return } \\
\text { (\%pa) }\end{array}$ & $\begin{array}{l}\text { excess } \\
\text { return } \\
\text { (\%pa) }\end{array}$ & $\begin{array}{c}\text { standard } \\
\text { deviation } \\
\text { (\%pa) }\end{array}$ & $\begin{array}{c}\text { best } \\
\text { month (\%) }\end{array}$ & $\begin{array}{c}\text { worst } \\
\text { month (\%) }\end{array}$ & beta & skew & kurtosis & liquidity \\
\hline Listed infrastructure and utilities & 7.9 & 4.3 & 16.1 & 13.5 & -14.0 & 0.49 & -0.67 & 0.92 & 0.13 \\
\hline Listed infrastructure & 4.0 & 1.0 & 57.1 & 50.8 & -53.8 & 1.82 & -0.47 & 2.83 & -0.09 \\
\hline Listed utilities & 7.9 & 4.3 & 16.2 & 12.4 & -14.0 & 0.57 & -0.67 & 0.91 & 0.12 \\
\hline Australia (in AUD) & $\begin{array}{l}\text { total } \\
\text { return } \\
\text { (\%ра) }\end{array}$ & $\begin{array}{l}\text { excess } \\
\text { return } \\
\text { (\%pa) }\end{array}$ & $\begin{array}{c}\text { standard } \\
\text { deviation } \\
\text { (\%pa) }\end{array}$ & $\begin{array}{c}\text { best } \\
\text { month (\%) }\end{array}$ & $\begin{array}{c}\text { worst } \\
\text { month (\%) }\end{array}$ & beta & skew & kurtosis & liquidity \\
\hline Listed Infrastructure and utilities & 16.2 & 10.5 & 15.2 & 13.5 & -13.0 & 0.63 & -1.10 & 2.92 & 0.16 \\
\hline Listed infrastructure & 16.3 & 10.6 & 48.4 & 17.4 & -24.6 & 0.67 & -0.73 & 3.02 & 0.04 \\
\hline Listed utilities & 17.3 & 11.6 & 15.8 & 20.9 & -10.4 & 0.56 & 0.25 & 1.97 & -0.03 \\
\hline Unlisted infrastructure and utilities & 12.1 & 6.4 & 6.1 & 8.9 & -2.4 & 0.06 & 1.94 & 5.19 & 0.00 \\
\hline
\end{tabular}


Table 3

Estimation of Augmented Fama French-GARCH model for monthly infrastructure fund returns, 1995-2009

This table presents the estimation of the augmented Fama-French GJR-GARCH model based on mean equation (1) and variance equation (4) applied to historical monthly data for 1995-2009 (total of 180 observations). In the mean equation, the dependent variable $\left(R_{i t}-R_{f t}\right)$ represents the excess return of infrastructure strategy $i$ at times $t$ and is regressed on the equity risk premium $\left(R_{m}-R_{f t}\right)$, the small cap premium $(S M B)$ and the value premium $(H M L)$. Returns are net of fees in USD for the US market and in AUD for the Australian market. In the variance equation, the fitted value of the conditional variance of strategy $i\left(h_{i t}\right)$ depends on the squared error of the previous period $\left(\varepsilon_{i, t-1}{ }^{2}\right)$, the variance of the previous period $\left(h_{i, t-1}\right)$ and the leverage effect $\left(\varepsilon_{i, t-1}^{2} I_{t-1}\right) *$ significant at the 10 per cent level $* *$ significant at the 5 per cent level $* * *$ significant at the 1 per cent level $\wedge^{\wedge}$ data available from August 1998 onwards.

\begin{tabular}{|c|c|c|c|c|c|c|c|}
\hline \multirow[t]{2}{*}{ Model } & \multicolumn{7}{|c|}{$\begin{array}{c}R_{i t}-R_{f t}=\alpha_{i}+\beta_{i, m}\left(R_{m, t}-R_{f t}\right)+\beta_{i, s} * S M B_{t}+\beta_{i, v} * H M L_{t}+\varepsilon_{i t} \\
h_{i t}=\gamma_{0}+\gamma_{1} \varepsilon_{i, t-1}^{2}+\gamma_{2} h_{i, t-1}+\gamma_{3} \varepsilon_{i, t-1}^{2} I_{t-l}\end{array}$} \\
\hline & $\begin{array}{c}\text { U.S. } \\
\text { Listed } \\
\text { Infrastructure^ }^{\wedge}\end{array}$ & $\begin{array}{l}\text { U.S. } \\
\text { Listed } \\
\text { Utilities }\end{array}$ & $\begin{array}{c}\text { U.S. } \\
\text { Listed } \\
\text { Infrastructure and } \\
\text { Utilities }\end{array}$ & $\begin{array}{l}\text { Australian } \\
\text { Listed } \\
\text { Infrastructure }\end{array}$ & $\begin{array}{l}\text { Australian Listed } \\
\text { Utilities }\end{array}$ & $\begin{array}{c}\text { Australian Listed } \\
\text { Infrastructure and } \\
\text { Utilities }\end{array}$ & $\begin{array}{c}\text { Australian Unlisted } \\
\text { Infrastructure and Utilities }\end{array}$ \\
\hline$\alpha$ & $0.0103^{* *}$ & 0.0024 & 0.0025 & $0.0060^{*}$ & $0.0064^{* *}$ & $0.0061^{* *}$ & $0.0042^{* *}$ \\
\hline$\beta_{\mathrm{m}}$ & $1.3579 * * *$ & $0.4723^{* * * *}$ & $0.4825^{* * *}$ & $0.6669^{* * * *}$ & $0.5734 * * *$ & $0.6266^{* * *}$ & $0.0771^{*}$ \\
\hline$\beta_{\mathrm{s}}$ & $0.6356^{* * * *}$ & -0.0660 & -0.0655 & $0.2261 *$ & $0.2092 * * *$ & $0.2157 * *$ & -0.0323 \\
\hline$\beta_{v}$ & $-0.5805^{* * *}$ & $0.2653^{* * * *}$ & $0.2619 * * *$ & $0.3712^{* *}$ & 0.1623 & $0.4199 * * *$ & 0.0649 \\
\hline$\gamma_{0}$ & $0.0002^{* *}$ & $0.0014^{* * * *}$ & $0.0014 * * *$ & 0.0023 & 0.0010 & 0.0000 & $0.0001^{* * *}$ \\
\hline$\gamma_{1 \text { (ARCH) }}$ & -0.0837 & $0.4184^{*}$ & 0.4178 & -0.0827 & -0.0379 & 0.1014 & $-0.0525^{* * * *}$ \\
\hline$\gamma_{2(\mathrm{GARCH})}$ & $0.8950^{* * * *}$ & -0.0884 & -0.0591 & 0.2862 & 0.4030 & $0.9138 * * *$ & $0.5041^{* * * *}$ \\
\hline$\gamma_{3}$ & 0.2372 & -0.4220 & -0.4219 & 0.3993 & -0.0845 & -0.1108 & 0.0463 \\
\hline$\gamma_{1}+\gamma_{2}+0.5 \gamma_{3}$ & 0.9299 & 0.1199 & 0.1477 & 0.4031 & 0.3228 & 0.9598 & 0.4747 \\
\hline $\mathrm{t}$-dist errors & $6.2353 * *$ & 13.0713 & 12.3898 & $3.5431 * * *$ & 19.7185 & 10.3755 & 19.9963 \\
\hline $\operatorname{Adj} R^{2}$ & 0.3405 & 0.2518 & 0.2605 & 0.1833 & 0.2240 & 0.3261 & 0.0105 \\
\hline Log Likelihood & 125.45 & 329.21 & 330.56 & 273.22 & 329.91 & 348.96 & 490.77 \\
\hline
\end{tabular}


Table 4

Estimation of Augmented Treynor-Mazuy-GARCH model for monthly infrastructure fund returns, 1995-2009

This table presents the Treynor and Mazuy (market timing) model based on mean equation (2) and variance equation (4) applied to historical monthly data for 19952009 (total of 180 observations). The variables are as defined for Table 3 with a market timing factor $\left(R_{m t}-R_{f t}\right)^{2}$.* significant at the 10 per cent level $* *$ significant at the 5 per cent level $* * *$ significant at the 1 per cent level $\wedge$ data available from August 1998 onwards.

\begin{tabular}{|c|c|c|c|c|c|c|c|}
\hline \multirow[t]{2}{*}{ Model } & \multicolumn{7}{|c|}{$\begin{array}{c}R_{i t}-R_{f t}=\alpha_{i}+\beta_{i, m}\left(R_{m, t}-R_{f t}\right)+\beta_{i, s} * S M B_{t}+\beta_{i, v} * H M L_{t}+\beta_{i, t \text { timing }}\left(R_{m t}-R_{f t}\right)^{2}+\varepsilon_{i t} \\
h_{i t}=\gamma_{0}+\gamma_{1} \varepsilon_{i, t-1}^{2}+\gamma_{2} h_{i, t-l}+\gamma_{3} \varepsilon_{i, t-1} I_{t-l}\end{array}$} \\
\hline & $\begin{array}{c}\text { U.S. } \\
\text { Listed } \\
\text { Infrastructure }^{\wedge}\end{array}$ & $\begin{array}{l}\text { U.S. } \\
\text { Listed } \\
\text { Utilities }\end{array}$ & $\begin{array}{c}\text { U.S. } \\
\text { Listed } \\
\text { Infrastructure and } \\
\text { Utilities } \\
\end{array}$ & $\begin{array}{l}\text { Australian } \\
\text { Listed } \\
\text { Infrastructure }\end{array}$ & $\begin{array}{l}\text { Australian Listed } \\
\text { Utilities }\end{array}$ & $\begin{array}{c}\text { Australian Listed } \\
\text { Infrastructure and } \\
\text { Utilities }\end{array}$ & $\begin{array}{c}\text { Australian Unlisted } \\
\text { Infrastructure and Utilities }\end{array}$ \\
\hline$\alpha$ & 0.0099 & 0.0020 & 0.0056 & 0.0069 & 0.0046 & 0.0051 & $0.0041^{* * *}$ \\
\hline$\beta_{\mathrm{m}}$ & $1.3693 * * *$ & $0.4603 * * *$ & $0.4478^{* * *}$ & $0.6552^{* * *}$ & $0.6094 * * *$ & $0.6446^{* * *}$ & $0.0673^{*}$ \\
\hline$\beta_{\mathrm{s}}$ & $0.6338 * *$ & -0.0746 & -0.1023 & 0.2114 & $0.2265^{* *}$ & $0.2080^{* *}$ & -0.0474 \\
\hline$\beta_{\mathrm{v}}$ & $-0.5825^{* * *}$ & $0.1887 * * *$ & $0.2552 * * *$ & $0.3735^{* *}$ & 0.1425 & $0.3816^{* * * *}$ & 0.0778 \\
\hline$\beta_{\text {timing }}$ & 0.2233 & -0.7882 & $-1.4990^{* *}$ & -0.5654 & 1.6028 & 0.3796 & -0.2969 \\
\hline$\gamma_{0}$ & $0.0002 *$ & $0.0021 * * *$ & $0.0012 * * *$ & 0.0023 & 0.0010 & 0.0014 & 0.0001 \\
\hline$\gamma_{I \text { (ARCH) }}$ & -0.0845 & 0.2819 & 0.4289 & -0.0887 & $-0.0438^{* * *}$ & -0.0793 & $-0.0532 * * *$ \\
\hline$\gamma_{2}$ (GARCH) & $0.8956^{* * * *}$ & -0.3570 & 0.0320 & 0.2728 & 0.4015 & -0.1017 & 0.5019 \\
\hline$\gamma_{3}$ & 0.2370 & -0.2876 & -0.4277 & 0.3898 & $-0.0756^{* * *}$ & 0.0657 & 0.0185 \\
\hline$\gamma_{1}+\gamma_{2}+0.5 \gamma_{3}$ & 0.9296 & -0.2189 & 0.2470 & 0.3790 & 0.3199 & -0.1481 & 0.4579 \\
\hline $\mathrm{t}$-dist errors & $6.2508^{* *}$ & 22.3839 & 10.3255 & $3.6343 * *$ & 19.6198 & 10.7132 & 19.9938 \\
\hline Adj $R^{2}$ & 0.3362 & 0.2548 & 0.2632 & 0.1819 & 0.2255 & 0.3227 & 0.0023 \\
\hline Log Likelihood & 125.46 & 329.67 & 331.95 & 273.27 & 330.33 & 347.13 & 491.38 \\
\hline
\end{tabular}


Table 5

Estimation of inflation hedging model for monthly infrastructure fund returns, 1995-2009

This table presents estimation results for the inflation hedging model of infrastructure investment returns based on mean equation (3) and variance equation (4) applied to historical monthly data for 1995-2009 (total of 180 observations). The variables are as defined for Table 3. In addition, in the mean equation, an inflation hedging factor TIPS is added. * significant at the 10 per cent level ** significant at the 5 per cent level *** significant at the 1 per cent level $\wedge$ data available from August 1998 onwards.

\begin{tabular}{|c|c|c|c|c|c|c|c|}
\hline \multirow[t]{2}{*}{ Model } & \multicolumn{7}{|c|}{$\begin{array}{c}R_{i t}-R_{f t}=\alpha_{i}+\beta_{i, m}\left(R_{m, t}-R_{f f}\right)+\beta_{i, s} * S M B_{t}+\beta_{i, v} * H M L_{t}+\beta_{i, i n f l a t i o n} * T I P S+\varepsilon_{i t} \\
h_{i t}=\gamma_{0}+\gamma_{1} \varepsilon_{i, t-1}^{2}+\gamma_{2} h_{i, t-1}+\gamma_{3} \varepsilon_{i, t-1}^{2} I_{t-1}\end{array}$} \\
\hline & $\begin{array}{c}\text { U.S. } \\
\text { Listed } \\
\text { Infrastructure^ }\end{array}$ & $\begin{array}{c}\text { U.S. } \\
\text { Listed } \\
\text { Utilities }\end{array}$ & $\begin{array}{c}\text { U.S. } \\
\text { Listed } \\
\text { Infrastructure and } \\
\text { Utilities } \\
\end{array}$ & $\begin{array}{c}\text { Australian } \\
\text { Listed } \\
\text { Infrastructure^^}\end{array}$ & $\begin{array}{l}\text { Australian Listed } \\
\text { Utilities }\end{array}$ & $\begin{array}{l}\text { Australian Listed Infrastructure } \\
\text { and Utilities }\end{array}$ & $\begin{array}{c}\text { Australian Unlisted } \\
\text { Infrastructure and Utilities }\end{array}$ \\
\hline$\alpha$ & $0.0101 *$ & 0.0020 & 0.0021 & 0.0033 & $0.0069 * *$ & $0.0055^{* *}$ & $0.0041 * * *$ \\
\hline$\beta_{\mathrm{m}}$ & $1.3368 * * *$ & $0.4654 * * *$ & $0.4740 * * *$ & $0.9950 * * *$ & $0.5560 * * *$ & $0.5971 * * *$ & $0.0848 * *$ \\
\hline$\beta_{\mathrm{s}}$ & 0.6566 *** & -0.0702 & -0.0698 & $0.1853 * *$ & $0.1955^{*}$ & $0.2548 * * *$ & -0.0366 \\
\hline$\beta_{\mathrm{v}}$ & $-0.5812 * * *$ & $0.2579 * * *$ & $0.2558 * * *$ & 0.1355 & 0.2092 & $0.4109 * * *$ & 0.0751 \\
\hline$\beta_{\text {inflation }}$ & 0.1306 & $0.4007 * *$ & $0.4062 * * *$ & -0.2441 & 0.2666 & $0.5731 * * *$ & -0.0028 \\
\hline$\gamma_{0}$ & $0.0002^{*}$ & $0.0012 * * *$ & $0.0012 * * *$ & 0.0001 & 0.0011 & 0.0000 & 0.0001 \\
\hline$\gamma_{I \text { (ARCH) }}$ & -0.0836 & 0.4478 & 0.4509 & 0.0598 & -0.0254 & 0.1259 & -0.0545 \\
\hline$\gamma_{2(\mathrm{GARCH})}$ & $0.8950^{* * *}$ & -0.0097 & 0.0341 & $0.8497 * * *$ & 0.4870 & $0.8970 * * *$ & 0.5025 \\
\hline$\gamma_{3}$ & 0.2365 & -0.4460 & -0.4485 & 0.1671 & -0.1296 & -0.1298 & 0.0388 \\
\hline$\gamma_{1}+\gamma_{2}+0.5 \gamma_{3}$ & 0.9296 & 0.2151 & 0.2675 & 0.9930 & 0.3968 & 0.9580 & 0.4673 \\
\hline$t$-dist errors & $6.3184 * * *$ & 11.4158 & 10.5438 & $3.6450 * * *$ & 19.9298 & 10.7616 & 19.9954 \\
\hline Adj $R^{2}$ & 0.3329 & 0.2636 & 0.2727 & 0.4684 & 0.2287 & 0.3539 & 0.0044 \\
\hline Log Likelihood & 125.52 & 331.77 & 333.28 & 325.27 & 327.79 & 354.14 & 490.20 \\
\hline
\end{tabular}


Table 6

Comparison of returns to regulated versus unregulated assets (January 1995 - December 2009)

This table presents a comparison of a direct investment into infrastructure and utilities to option models. Log returns are based on monthly data from January 1995 to December 2009 in USD or AUD (total of 180 observations). Risk is annualised by multiplying monthly standard deviation by the square root of 12 . Reward to risk is calculated by dividing return by risk. Winning months represents the number of months that returns were positive. Skew and kurtosis represent the skew and kurtosis of the monthly returns. Best month represents the month with the highest monthly return. Worst month represents the month with the lowest monthly return. Beta is measured by calculating the slope of the strategy returns against the equity markets (the S\&P 500 or ASX 300). ROE cap in row 10 represents the cap on earnings growth and impacts the covered call strike level. Regulatory premium in rows 12 to 14 measures the difference in returns between the equity market return and the covered call strategy, without assumed government intervention (no floor), and with government intervention after a 75 per cent and a 50 per cent share price decline.

\section{Panel A: US markets}

\begin{tabular}{|c|c|c|c|c|c|c|c|c|c|}
\hline & & $A$ & B & C & $\mathrm{D}$ & $E$ & $\mathrm{~F}$ & $G$ & $\mathrm{H}$ \\
\hline & & \multicolumn{8}{|c|}{ Covered call - monthly strike level (\%) } \\
\hline & & $\begin{array}{l}\text { Infra \& } \\
\text { Utilities }\end{array}$ & 0.83 & 0.92 & 1.00 & 1.08 & 1.17 & 1.25 & $\begin{array}{l}\text { S\&P } \\
500\end{array}$ \\
\hline 1 & Return (\%pa) & 7.9 & 9.4 & 9.5 & 9.6 & 9.7 & 9.8 & 9.9 & 7.7 \\
\hline 2 & Risk (\%pa) & 16.1 & 11.0 & 11.1 & 11.2 & 11.3 & 11.4 & 11.4 & 16.0 \\
\hline 3 & Reward to risk & 0.5 & 0.9 & 0.9 & 0.9 & 0.9 & 0.9 & 0.9 & 0.5 \\
\hline 4 & Winning months (\%) & 62 & 74 & 73 & 73 & 73 & 73 & 73 & 64 \\
\hline 5 & Skew & -0.7 & -2.1 & -2.1 & -2.1 & -2.1 & -2.0 & -2.0 & -1.0 \\
\hline 6 & Kurtosis & 0.9 & 6.6 & 6.4 & 6.2 & 6.1 & 6.0 & 5.8 & 1.7 \\
\hline 7 & Best month (\%) & 13.5 & 5.2 & 5.2 & 5.3 & 5.3 & 5.4 & 5.4 & 9.3 \\
\hline 8 & Worst month (\%) & -14.0 & -16.3 & -16.3 & -16.3 & -16.4 & -16.4 & -16.4 & -18.4 \\
\hline 9 & Beta to equity market & 0.5 & 0.6 & 0.6 & 0.6 & 0.6 & 0.7 & 0.7 & 1.0 \\
\hline 10 & ROE cap (\%pa) & & 10.0 & 11.0 & 12.0 & 13.0 & 14.0 & 15.0 & \\
\hline \multicolumn{10}{|c|}{ egulatory premium (\% pa) } \\
\hline 12 & No floor & & 1.6 & 1.7 & 1.9 & 2.0 & 2.1 & 2.2 & \\
\hline 13 & $75 \%$ floor & & 1.1 & 1.2 & 1.3 & 1.4 & 1.5 & 1.6 & \\
\hline 14 & $50 \%$ floor & & 0.7 & 0.9 & 1.0 & 1.1 & 1.2 & 1.3 & \\
\hline
\end{tabular}

\begin{tabular}{|c|c|c|c|c|c|c|c|}
\hline$A$ & $\mathrm{~B}$ & C & D & $E$ & $\mathrm{~F}$ & $\mathrm{G}$ & $\mathrm{H}$ \\
\hline \multicolumn{8}{|c|}{ Covered call - quarterly strike level (\%) } \\
\hline $\begin{array}{l}\text { Infra \& } \\
\text { Utilities } \\
\end{array}$ & 2.50 & 2.75 & 3.00 & 3.25 & 3.50 & 3.75 & $\begin{array}{l}\text { ASX } \\
300 \\
\end{array}$ \\
\hline 16.2 & 13.9 & 14.0 & 14.1 & 14.2 & 14.3 & 14.3 & 10.2 \\
\hline 15.2 & 9.0 & 9.1 & 9.3 & 9.4 & 9.6 & 9.7 & 13.0 \\
\hline 1.1 & 1.5 & 1.5 & 1.5 & 1.5 & 1.5 & 1.5 & 0.8 \\
\hline 65 & 88 & 88 & 87 & 87 & 87 & 87 & 66 \\
\hline-1.1 & -2.2 & -2.2 & -2.1 & -2.1 & -2.0 & -2.0 & -1.0 \\
\hline 2.9 & 5.3 & 5.1 & 4.9 & 4.7 & 4.5 & 4.3 & 1.7 \\
\hline 13.5 & 9.1 & 9.3 & 9.4 & 9.6 & 9.7 & 9.8 & 7.8 \\
\hline-13.0 & -14.9 & -15.0 & -15.1 & -15.2 & -15.3 & -15.4 & -13.8 \\
\hline \multirow[t]{5}{*}{0.6} & 0.6 & 0.6 & 0.7 & 0.7 & 0.7 & 0.7 & 1.0 \\
\hline & 10.0 & 11.0 & 12.0 & 13.0 & 14.0 & 15.0 & \\
\hline & 3.6 & 3.8 & 3.9 & 3.9 & 4.0 & 4.1 & \\
\hline & 3.2 & 3.3 & 3.4 & 3.5 & 3.6 & 3.7 & \\
\hline & 2.6 & 2.8 & 2.9 & 2.9 & 3.0 & 3.1 & \\
\hline
\end{tabular}


Table 7

Comparison of returns on direct infrastructure investment and synthetic asset

This table presents a comparison of the characteristics of a direct infrastructure investment versus replication using exchange traded instruments comprising covered calls and inflation linked bonds. Out-of-sample returns are based on monthly data from January 1998 to December 2009 in USD or AUD (total of 144 observations). Risk is annualised by multiplying monthly standard deviation by the square root of 12. Reward to risk is calculated by dividing return by risk. Winning months represents the number of months that returns were positive. Skew and kurtosis represent the skew and kurtosis of the monthly returns. Best month represents the month with the highest monthly return. Worst month represents the month with the lowest monthly return. Beta to the stock market is measured by calculating the slope of the strategy returns against the S\&P 500 or ASX 300 total return index. Beta to inflation measures the slope against the inflation linked bond total return index.

\begin{tabular}{|c|c|c|c|c|c|c|}
\hline & $\begin{array}{l}\text { U.S. Infrastructure } \\
\text { and Utilities }\end{array}$ & Replicator & & $\begin{array}{c}\text { Australian } \\
\text { Infrastructure and } \\
\text { Utilities }\end{array}$ & $\begin{array}{l}\text { Australian unlisted } \\
\text { Infrastructure and } \\
\text { Utilities }\end{array}$ & Replicator \\
\hline Return (\%pa) & 5.0 & 6.6 & Return (\%pa) & 12.3 & 11.4 & 9.1 \\
\hline Risk (\%pa) & 17.1 & 6.7 & Risk (\%pa) & 15.2 & 6.1 & 6.0 \\
\hline Wining months & $61 \%$ & $74 \%$ & Wining months & $64 \%$ & $78 \%$ & $76 \%$ \\
\hline Skew & -0.6 & -2.4 & Skew & -0.1 & 2.1 & -1.2 \\
\hline Kurtosis & 0.6 & 14.7 & Kurtosis & 1.0 & 6.1 & 3.6 \\
\hline Best month (\%) & 12.2 & 6.8 & Best month (\%) & 13.5 & 8.9 & 4.8 \\
\hline Beta to inflation & 0.5 & 0.7 & Beta to inflation & 0.5 & 0.1 & 0.5 \\
\hline
\end{tabular}


Table 8

Defensive abilities of direct investment compared to synthetic asset under simulated conditions

This table presents a comparison of the downside risk. 1,000 runs of 12 annual returns are created for both the direct investment and the synthetic asset by using resampling with replacement from the monthly historical data (total of 180 observations), to create a total of 144,000 simulated data points (1,000 runs x 12 years x 12 months). Monthly Value at Risk (VaR) and Expected Shortfall (ES) are then calculated under simulated conditions. Value at Risk refers to the percentile threshold which is not expected to be exceeded in more than 5 per cent of the cases. Expected shortfall measures the average of all observations below the 5 th percentile.

\begin{tabular}{llcccc}
\hline & \multicolumn{2}{c}{ US market } & \multicolumn{2}{c}{ Australian market } \\
& & VaR & ES & VaR & ES \\
\hline \multirow{2}{*}{ Direct Investment } & Mean (\%) & -7.6 & -11.2 & -6.1 & -8.3 \\
& Standard deviation (\%) & 1.5 & 1.3 & 0.6 & 1.0 \\
\multirow{3}{*}{ Synthetic asset } & -2.5 & -5.3 & -2.2 & -3.7 \\
& Mean (\%) & 0.7 & 1.3 & 0.5 & 0.6 \\
& Standard deviation (\%) & 0.7 & & \\
\hline
\end{tabular}

